\title{
The Quagga project: progress over 20 years of selective breeding
}

\author{
Eric H. Harley ${ }^{1 \star}$, Michael H. Knight ${ }^{2}$, Craig Lardner ${ }^{3}$, \\ Bernard Wooding ${ }^{4}$ \& Michael Gregor ${ }^{4}$ \\ ${ }^{1}$ Department of Clinical Laboratory Sciences, University of Cape Town, Observatory, 7925 South Africa \\ ${ }^{2}$ South African National Parks, P.O. Box 20419, Humewood, Port Elizabeth, 6013 South Africa, and \\ Department of Zoology, Nelson Mandela Metropolitan University, Port Elizabeth \\ ${ }^{3}$ Far Horizons Wine Estate, Windmeul, 7630 South Africa \\ ${ }^{4}$ Elandsberg Farms, Hermon, 7308 South Africa \\ Received 22 July 2008. Accepted 13 July 2009
}

\begin{abstract}
The quagga project has now been in progress for over 20 years. Its aim, given conclusive molecular evidence that the quagga and the plains zebra, Equus quagga, are conspecific, is the retrieval of the pelage characteristics of the quagga by selective breeding from a selected panel of plains zebra individuals. The programme has now over 25 third generation progeny, and is starting to produce individuals with a degree of striping reduction shown by none of the original founders and which approximate the striping pattern shown by at least some of the known museum specimens of quagga. These results indicate that by the fourth generation the project should have largely succeeded in its aim, and will form the basis of a herd of individuals which can be displayed in the Western Cape as an illustration of a phenotype which had disappeared from extant populations of plains zebra.
\end{abstract}

Key words: plains zebra, quagga, selective breeding.

\section{INTRODUCTION}

The quagga (Equus quagga quagga) belongs to the mammalian order Perissodactyla, which includes rhinoceroses, tapirs and equids (horses, asses and zebras). There are three extant zebra species, namely the Grevy's (Equus grevyi), Mountain (E. zebra), and plains zebras (E. quagga) (or $E$. burchelli). The quagga was a zebra found in a region south of the Orange river in the Western Cape region of South Africa (Skead 1987). It was characterized by markedly reduced striping over the rear part of the body and on the legs, together with a generally brown colouring over the rear part of the body. Extensive hunting in the nineteenth century saw the demise of the quagga, with the last known quagga dying in Amsterdam Zoo in 1883. Only a single photograph (from the London Zoo) of a living quagga exists and 23 skins remain scattered throughout the world's museums.

There has been debate as to whether the quagga is a separate species or simply a colour variant of the plains zebra. Some have said it was a horse, whilst some still believe, mostly on the basis of measurements of museum skulls, that it was more closely related to the mountain zebra than to the plains zebra (Bennet 1980; Klein \& Cruz-Uribe

\footnotetext{
*To whom correspondence should be addressed.

E-mail: ehharley@gmail.com
}

1999). However, it needs to be borne in mind that it was easier for collectors to send a skin to a museum than the whole animal or the skeleton. Some taxidermists were not very discriminating in the skulls they used to assist in mounting their skins, and frequently used horse or donkey's skulls if the original quagga skull was unavailable, and this was not often recorded. So the use of skulls from mounted specimens is highly unreliable. Groves \& Bell (2004) have summarized this controversy, concluding that the quagga is indeed a variety of the plains zebra.

The history of the project began more than 20 years ago when Reinhold Rau sent material via Oliver Ryder, an animal conservationist at the Center for Reproduction of Endangered Species in San Diego, to Russel Higuchi in Allan Wilson's laboratory for molecular evolution at the University of California at Berkeley (and also to Lowenstein in San Francisco). Higuchi (Higuchi et al. 1984) cloned and sequenced some fragments of mitochondrial DNA from the tissue, which when compared with mountain and later plains zebra (Higuch et al. 1987) showed that the DNA was effectively identical to that of the plains zebra. An additional immunological study (Lowenstein 1985) came to the same conclusion. A later comprehensive DNA sequencing study using 
material from 13 museum quagga specimens (Leonard et al. 2005) provided conclusive evidence that the quagga and the plains zebra were indeed the same species, and that the quagga is just a colour variant of the plains zebra. This confirms the earlier suggestions (Rau 1978; Groves \& Bell 2004) that priority requires that the correct species designation for the plains zebra should be Equus quagga rather than the previously used Equus burchelli. This designation is now being widely applied (e.g. Lorenzen et al. 2008) and will therefore be used here. It is interesting to note that the name 'Quagga' describes the barking cry typical of the plains zebra.

These DNA sequencing studies provided the scientific basis for a proposal that a selective breeding programme might be successful in retrieving the genes responsible for the characteristic coat patterns of the quagga, if these genes are present in diluted form in the extant populations of the plains zebra. Relevant to the proposal was the parapatric distribution of quagga and plains zebra and the known wide variety of colour patterns seen in the extant plains zebra. This variation enabled animals to be chosen for such a programme which had aspects of their coat colour and striping patterns which had features tending towards those of the quagga.

A committee was therefore set up in 1986 consisting of zoologists, veterinarians, museum personnel, and a molecular biologist under the chairmanship of Mike Cluver of the then South African Museum to attempt this. In 1987 a total of 19 plains zebra from Etosha National Park, Namibia, and reserves in KwaZulu-Natal, South Africa were selected and housed initially at Vrolijkheid near McGregor, Western Cape, South Africa. These animals were chosen on the basis of demonstrable reduction in striping over the rear of the body or legs, or any suggestion of a darker overall background colour. This exploits the significant variation in striping and colour patterns existing in plains zebra, which show a gradient of progressive reduction in striping from north to south of their geographical distribution, together with the appearance in the south of lighter 'shadow' stripes between the dark stripes, which has been suggested to be an adaptation to open country, with the quagga representing the extreme limit of the trend (Rau 1974, 1978). Individuals with obviously deviant striping patterns were avoided in order not to include characters resulting from new mutations.

Of the original 19 founders, 18 produced off- spring, with the first foal being born in 1988. The growing herd was later distributed to a number of separate localities in the Western Cape to facilitate identification of pedigrees and to select appropriate grouping of individuals. Offspring, as might be expected, either showed heavier striping, lesser striping, or similar striping patterns to their parents, and as time progressed, those with heavier striping were removed, thereby providing the selection process necessary for the success of the project. It was estimated at the start of the project that about four generations of such selection should be sufficient to demonstrate the feasibility of simple selective breeding in producing the quagga phenotype. In keeping with the original aims of the project, the organization and running of the project was transferred to the South African National Parks in 2005 with one of us (M.H.K.) as chairman. This report describes the tools used to measure the progress of this selective breeding, and the results obtained in foals produced over the 20 years that the programme has been running.

\section{METHODS}

In order to monitor progress, animals are scored in terms of the number of stripes in five separate body areas (Fig. 1). The scoring scheme is deliberately kept simple, as photographing zebras in the field is not easy and photographs vary in quality. All animals are photographed from both sides in the field, and from these photographs stripes on the neck and body are counted. Stripes are counted as valid (scored) if they extend over halfway between the superior and inferior centrelines, and if they are unbroken. If there is a difference between left and right sides, the larger number is chosen. Shadow stripes are not included. On the legs all stripes are scored, even if they extend only part way around the leg. Background colour is scored on a scale of zero (dark brown) to three (white). This measure is particularly problematic, and depends on the exposure, the lighting, the time of year, and accumulation of dust on the body, and serves as at best a rough guide to progress in colour selection.

In order to follow progress over generations it is necessary to allocate a generation ( $F$ number) to each animal. As not all animals are simple progeny of, for example, first generation matings or pure second generation matings, the generation number of an individual was scored as the total steps through all members of the lineage from the original founder animals to the individual, divided by the number of founder individuals. If a founder appeared 


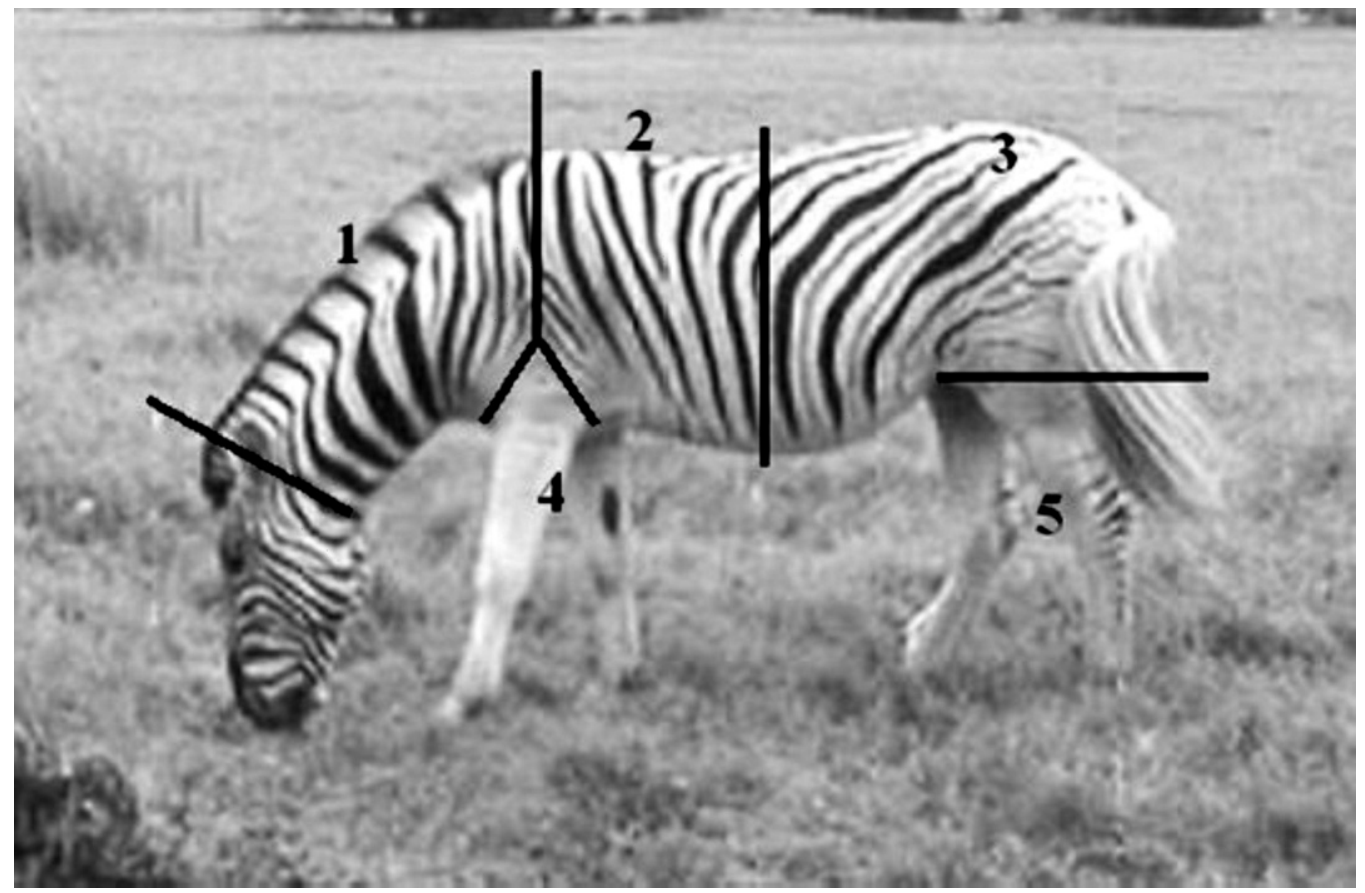

Fig. 1. Demarcation of areas scored for numbers of stripes. Using the criteria described, this individual would have scores of area 1, 8; area 2, 5; area 3, 3; area 4, 0; and area 5, 8.

twice or more in the pedigree each appearance was included in the total founder number. In this way individuals often received a fractional $F$ number, so for some analyses individuals are grouped into integral number generations by rounding their $\mathrm{F}$ number up or down accordingly, e.g. individuals with an $\mathrm{F}$ number of 2.6 , or 3.2 , would both be included in the overall 3rd generation category.

Probabilities associated with Student's $t$-test, 2-tailed and with 2-sample unequal variance, were used to measure the significance of difference in the striping and colour pattern between the founder population, the three generations of progeny so far produced in the project, museum quaggas, and a selection of 18 wild plains zebras, chosen randomly from clear detailed photographs supplied by the authors, colleagues in the conservancies and game reserves, or obtained from articles on plains zebra.

\section{RESULTS}

A total of 89 zebras were alive in the project at the beginning of 2008, spread across 12 separate localities. The results of changes in striping can be seen over three generations in Fig. 2, where the mean values for each generation, and their variation, are compared with those of a random sample of plains zebra and with museum quaggas. Table 1 details the pairwise tests of statistical significance for these comparisons. Significant reduction in stripe number between wild zebras and founders was seen in the hind body (area 3) and the legs, demonstrating effective selection of founders for initiating the selection programme. A progressive increase in the significance of stripe reduction was seen between founders and generations one to three in the hind-body, but less so in the leg striping. As expected, there was little of significance in comparative stripe numbers in the neck and forebody regions, except for forebody comparisons with museum quaggas. A significant decrease in striping over generations was also recorded in a subset of the project animals by Parsons et al. (2007) using a computer-based analytical method. Background colour estimates show no progressive change over time between founders and progeny generations.

The value of individual stallions and mares to the breeding programme was measured not just by comparison of their own individual striping scores, but also as a function of the mean stripe scores (hind body and/or legs) of their offspring. These measures, shown in Fig. 3 for stallions, clearly shows the breeding value of individuals, and 
a)

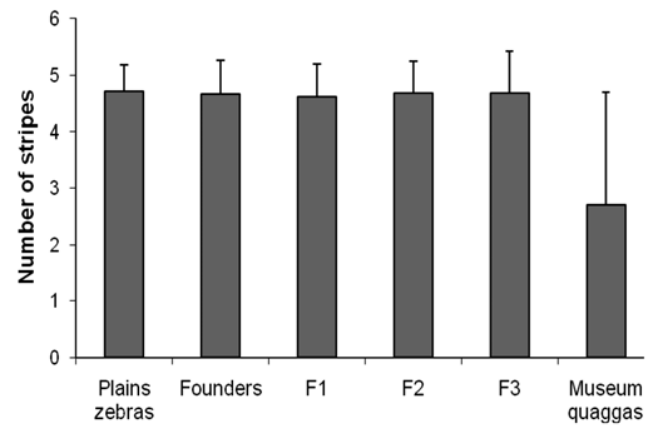

c)

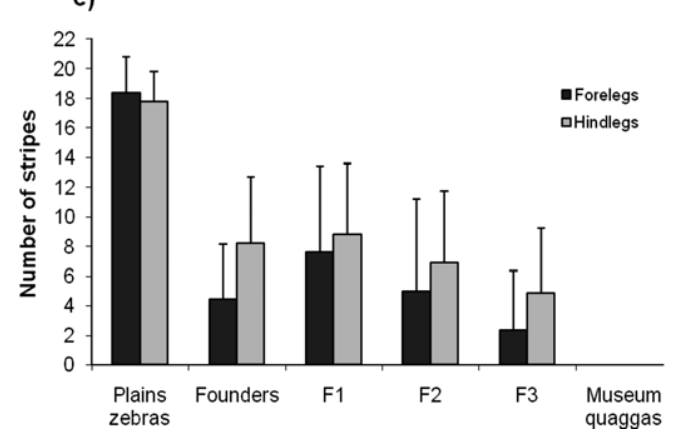

b)
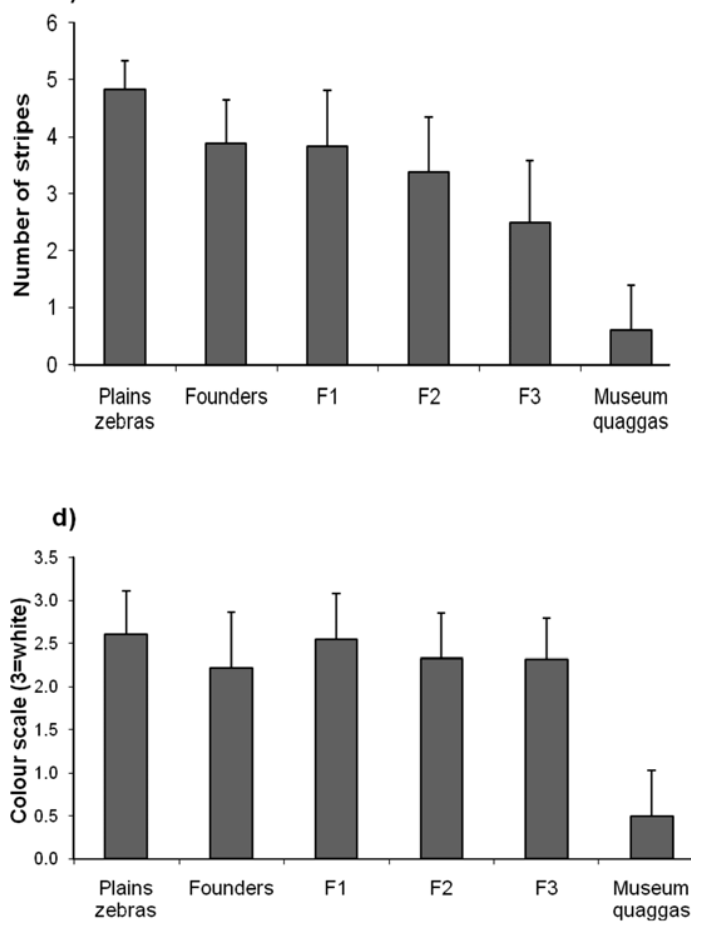

Fig. 2. Mean scores summarized over generations and compared with wild zebras and museum quaggas; $\mathbf{a}$, forebody stripes (area 2); b, hindbody stripes (area 3); c, leg stripes (area 4 and area 5); d, colour scores. Data are from 18 wild plains zebra, 18 project founders, 66 F1 generation project animals, 78 F2 generation animals, 25 F3 generation animals, and 10 museum quaggas. Error bars are standard deviations.

greatly assists in the selection process, whereby animals with mean foal striping values exceeding the mean become candidates for removal from the programme. Mean stripe scores in offspring of particular individuals are also useful when performing analyses on the accumulating data, and this is demonstrable in Fig. 4, where the correlation between stripe number on the hindbody and stripe number on the legs is plotted. The correlation between stripe number on hind-body with those on legs is quite weak when individual animals values are plotted $\left(R^{2}=0.084\right)$, but is markedly better when the mean foal values of individual stallions or mares are plotted $\left(R^{2}>0.4\right)$. The same applies to the correlation between the number of stripes on forelegs with those on hindlegs, although the overall correlation $R^{2}$ values here are considerably stronger.

\section{CONCLUSION}

Progress in mean stripe reduction (hind-body and legs) over generations is clearly evident with some late generation individuals in this regard now more closely resembling quaggas than typical plains zebra. One of the best third generation animals is illustrated in Fig. 5 together with two examples of plains zebra showing the variation in striping in this species, as well as two mounted museum quagga skins. Although there is little noticeable progress in darkening of the mean background colour, animals with the most marked reduction in striping do show intermediate values of background colour (one or two on the zero to three scale). This demonstrates that the project is on track, at least for striping reduction, with the best animals approximating to the patterns shown by some of the museum skins, which, as illustrated in Fig. 5, are themselves quite variable in both striping reduction and depth of background colour. The production in as little as three generations of individuals with a degree of stripe reduction seen in none of the founders implies significant variation in genes (or more probably, in the control regions affecting expression of such genes) affecting pelage characteristics in the founder population. This would be consistent with the high degree of 
Table 1. $t$-test probabilities for the comparisons between striping scores for the various areas (e.g. as illustrated in Fig. 2) and colour scores (NS = not significant at the $5 \%$ level).

\begin{tabular}{|c|c|c|c|c|c|}
\hline Area 1: Neck & Founders & $\mathrm{F} 1$ & $\mathrm{~F} 2$ & F3 & Quaggas \\
\hline Zebras & NS & NS & NS & NS & NS \\
\hline Founders & & NS & NS & NS & NS \\
\hline $\mathrm{F} 1$ & & & $<0.05$ & NS & NS \\
\hline $\mathrm{F} 2$ & & & & NS & NS \\
\hline F3 & & & & & NS \\
\hline Area 2: Forebody & Founders & $\mathrm{F} 1$ & $\mathrm{~F} 2$ & F3 & Quaggas \\
\hline Zebras & NS & NS & NS & NS & $<0.05$ \\
\hline Founders & & NS & NS & NS & $<0.05$ \\
\hline $\mathrm{F} 1$ & & & NS & NS & $<0.05$ \\
\hline $\mathrm{F} 2$ & & & & NS & $<0.05$ \\
\hline F3 & & & & & $<0.05$ \\
\hline Area 3: Hindbody & Founders & $\mathrm{F} 1$ & $\mathrm{~F} 2$ & F3 & Quaggas \\
\hline Zebras & $<0.01$ & $<0.01$ & $<0.01$ & $<0.01$ & $<0.01$ \\
\hline Founders & & NS & $<0.05$ & $<0.01$ & $<0.01$ \\
\hline $\mathrm{F} 1$ & & & $<0.01$ & $<0.01$ & $<0.01$ \\
\hline $\mathrm{F} 2$ & & & & $<0.01$ & $<0.01$ \\
\hline $\mathrm{F} 3$ & & & & & $<0.01$ \\
\hline Area 4: Forelegs & Founders & $\mathrm{F} 1$ & $\mathrm{~F} 2$ & F3 & Quaggas \\
\hline Zebras & $<0.01$ & $<0.01$ & $<0.01$ & $<0.01$ & $<0.01$ \\
\hline Founders & & $<0.01$ & NS & NS & $<0.01$ \\
\hline $\mathrm{F} 1$ & & & $<0.01$ & $<0.01$ & $<0.01$ \\
\hline $\mathrm{F} 2$ & & & & $<0.05$ & $<0.01$ \\
\hline $\mathrm{F} 3$ & & & & & $<0.01$ \\
\hline Area 5: Hindlegs & Founders & $\mathrm{F} 1$ & $\mathrm{~F} 2$ & F3 & Quaggas \\
\hline Zebras & $<0.01$ & $<0.01$ & $<0.01$ & $<0.01$ & $<0.01$ \\
\hline Founders & & NS & NS & $<0.05$ & $<0.01$ \\
\hline $\mathrm{F} 1$ & & & $<0.05$ & $<0.01$ & $<0.01$ \\
\hline $\mathrm{F} 2$ & & & & NS & $<0.01$ \\
\hline F3 & & & & & $<0.01$ \\
\hline Background colour & Founders & $\mathrm{F} 1$ & $\mathrm{~F} 2$ & F3 & Quaggas \\
\hline Zebras & NS & NS & $<0.05$ & NS & $<0.01$ \\
\hline Founders & & NS & NS & NS & $<0.01$ \\
\hline $\mathrm{F} 1$ & & & $<0.05$ & NS & $<0.01$ \\
\hline $\mathrm{F} 2$ & & & & NS & $<0.01$ \\
\hline F3 & & & & & $<0.01$ \\
\hline
\end{tabular}

genetic variation observed in plains zebra together with a remarkable lack of genetic differentiation between the different subspecies (Lorenzen et al. 2008), which implies that genes for most characteristics are spread widely through the whole plains zebra population. Some insight is also given into the functioning of such genes by the correlation shown between the number of stripes on the body and the legs, suggesting that a single gene is at least primarily responsible for the degree of striping in these areas. The wide variation between individuals suggests that such a gene, or its control region, is multiallelic, with most individuals being compound heterozygotes for these alleles. The project may provide an opportunity in the future for provision of data sets giving insights into the complex genetics of colour control.

Although it is necessary to note that there can be no certainty that the genes selected for by this breeding programme are the genes directly respon- 
a)

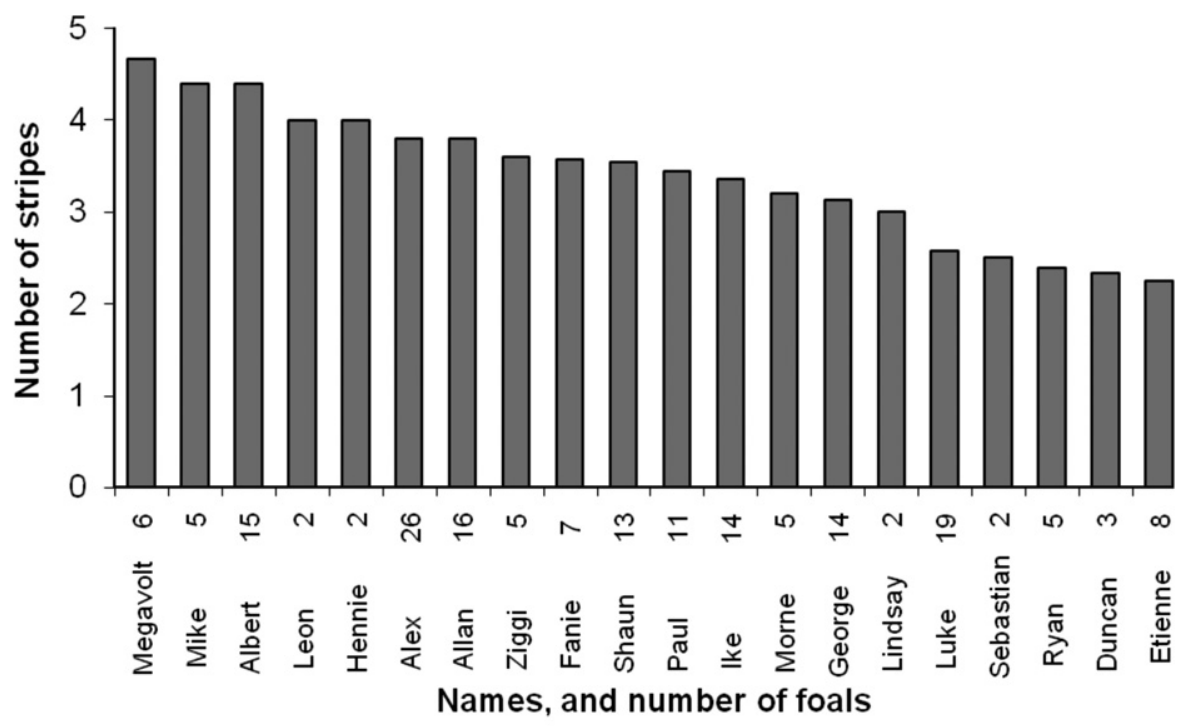

b)

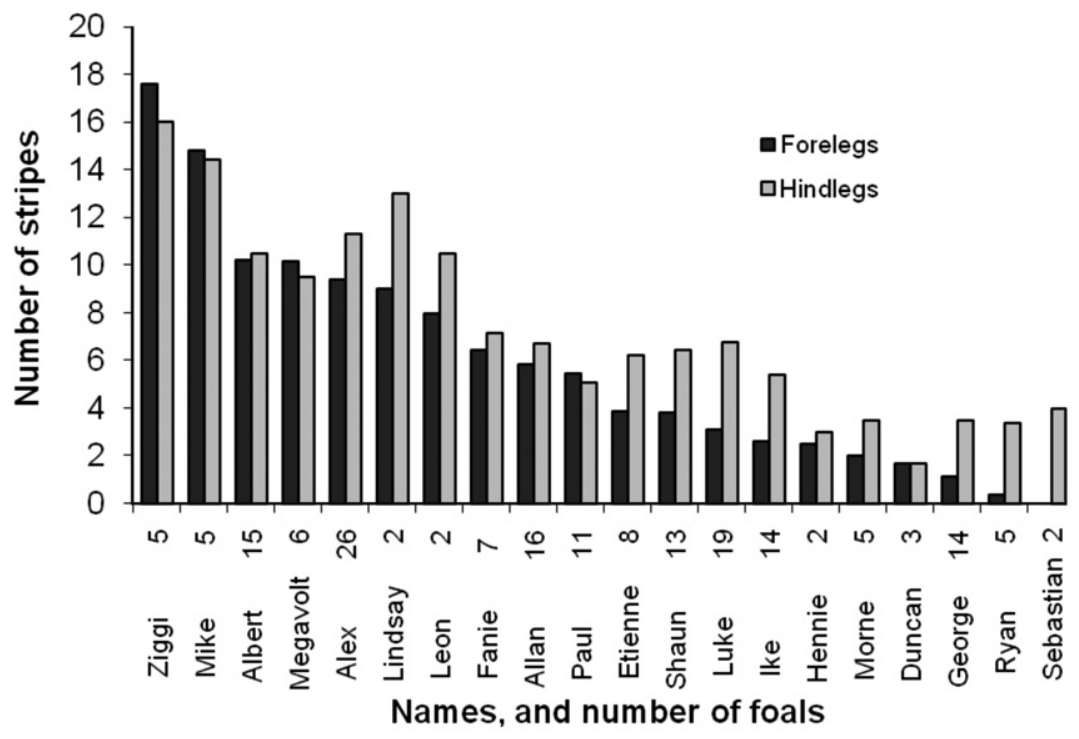

Fig. 3. Stallions scored and sorted by the mean number of stripes measured in their foals; $a$, in foals' hindbody region; b, in foals' fore- and hind legs.

sible for the original quagga phenotype, our results would be consistent with such a conclusion. A possible problem, given the relatively small number of founders, is future loss of genetic diversity, with possible concomitant inbreeding depression, from genetic drift and the selection process, and perhaps a limitation on movement of some traits (e.g. background colour) from the founders to the progeny.
This is best avoided by maintaining as large a body of animals in the project as is feasible and avoiding line breeding.

The project has not been without controversy some conservationists believe that even if an animal conforming to the striping and colour patterns of the quagga were produced, it would not correctly be described as a quagga because the 
a)

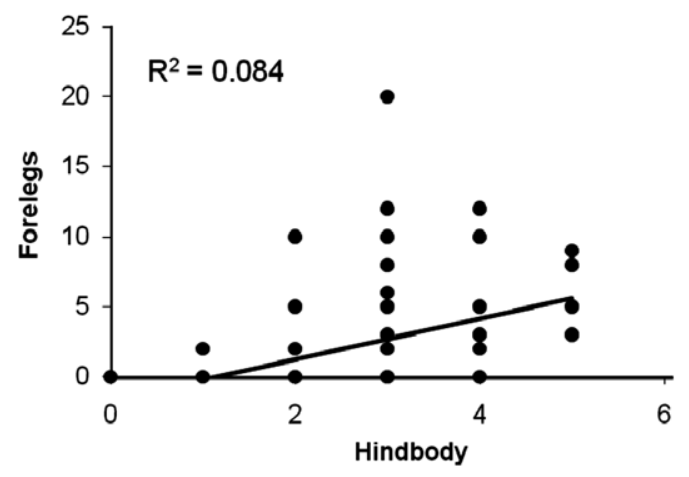

c)

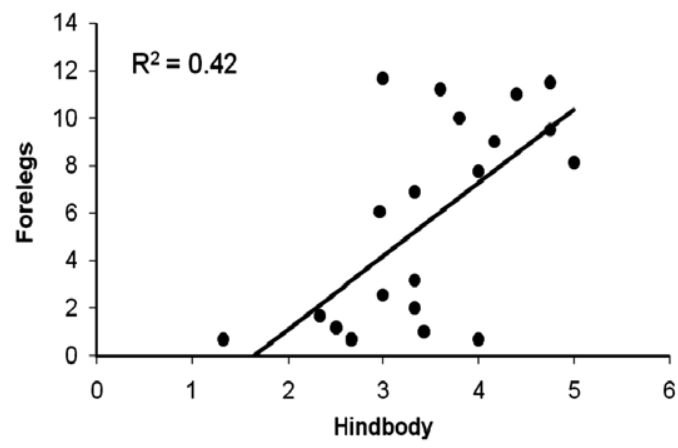

e)

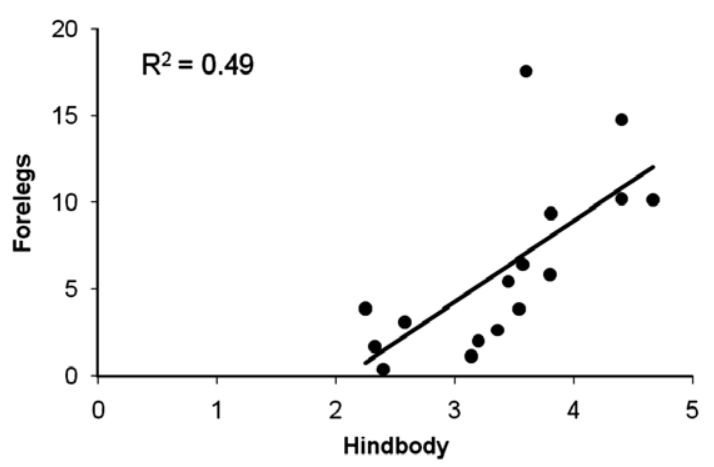

b)

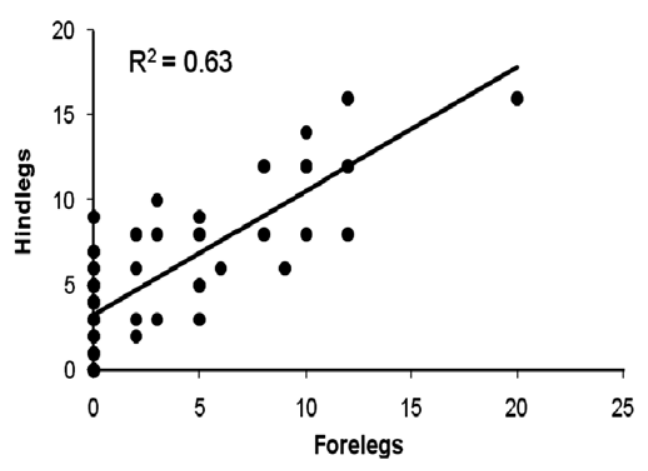

d)

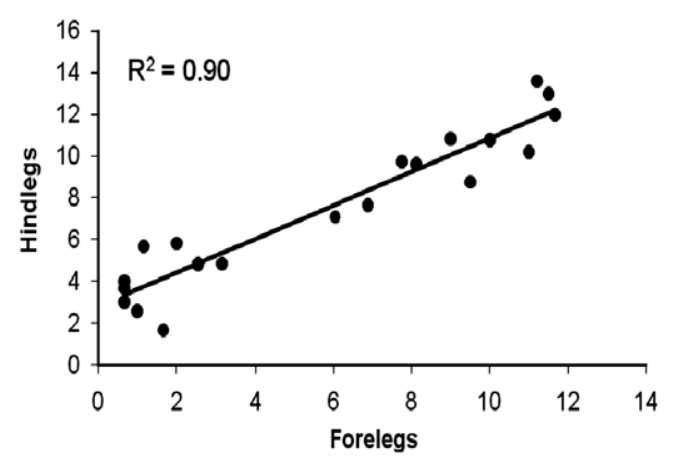

f)

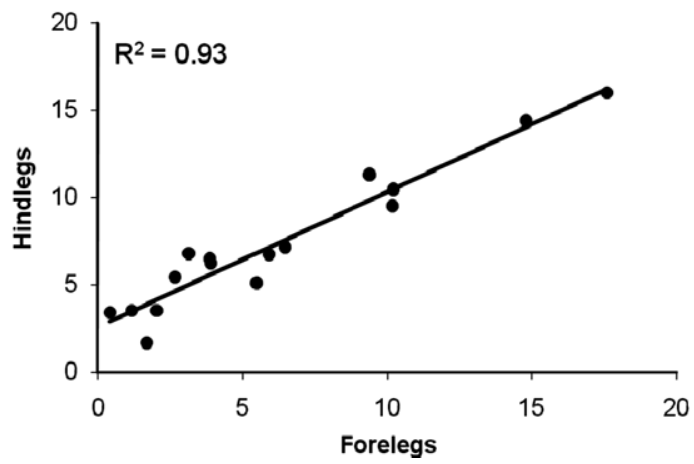

Fig. 4. Correlation of stripe numbers in different sectors; (a), (c) and (e) compare values in the hind body sector with those in the foreleg sector; (b), (d) and (f) compare values in the foreleg sector with those in the hindleg sector; (a) and (b) individual data from all mares and stallions alive in January 2008; (c) and (d) data are the mean values in mare's foals (mean number of foals = 5.76); (e) and (f) are the mean values in stallion's foals (mean number of foals $=10.75$ ).

original quaggas might have had other undescribed, and perhaps adaptive attributes, which distinguished them from plains zebra. This is plausible, although if it is not possible to define what these presumptive attributes were then it seems reasonable to propose that the quagga can be defined only by its known attributes, which are its coat patterns. If these are retrieved then describing the animals possessing them as representatives of the quagga phenotype is justified. The quagga 


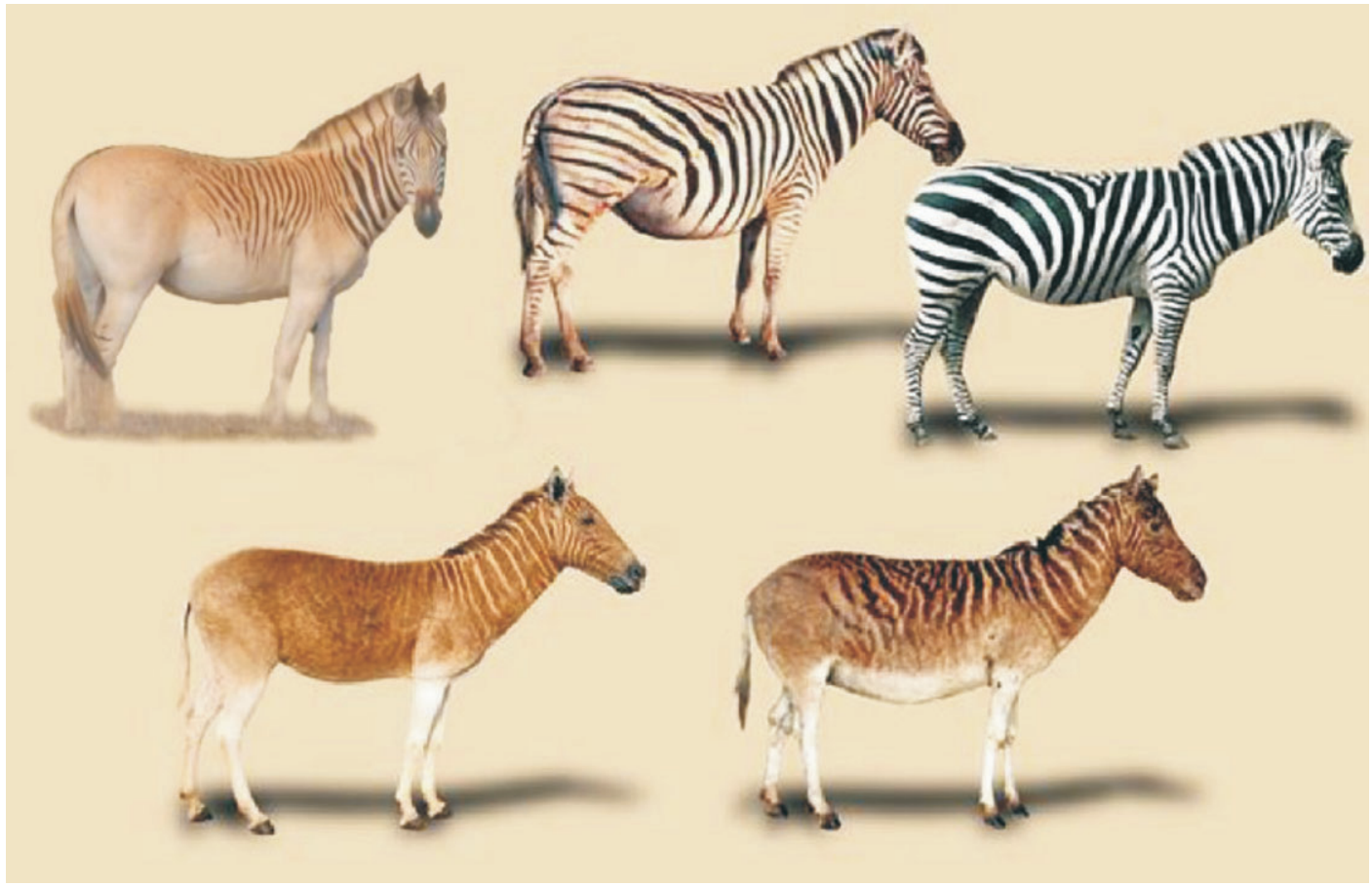

Fig. 5. A montage comparing a third generation quagga project individual (upper left) with, top row: two typical plains zebras, in the centre from the extreme westward part of the species range (Etosha) and on the right from the extreme eastward part, and, bottom row: two representative museum quaggas, on the left: the Munich quagga, on the right: the Tring quagga.

project is a uniquely South African venture which has captured world-wide interest and which is likely to be contributing significantly to the tourist attraction to the country, and to the Western Cape in particular, especially as the animals are accessible and can be seen in many localities around the general Cape Town area.

It appears likely that in the fourth generation the goal of achieving zero stripes on both hindbody and legs in a number of individuals is achievable. The eventual aim is to release these animals into a national reserve in the Western Cape (free, of course, of other plains zebra, to avoid interbreeding), enabling the visiting public to see a rendering of the zebra that the original occupants and settlers of the region would have encountered some hundreds of years ago, back into their original setting.

\section{ACKNOWLEDGEMENTS}

We acknowledge the immense contribution and inspiration of the late Reinhold Rau, who initiated and promoted the project from its inception, and thank the many participating landowners who have maintained project animals on their properties.

\section{REFERENCES}

BENNET, D.K. 1980. Stripes do not a zebra make, Part I: A cladistic analysis of Equus. Syst. Zool.29:272-287.

GROVES, C.P.\& BELL, C.H.2004. New investigations on the taxonomy of the zebras genus Equus, subgenus Hippotigris. Mamm. Biol. 69: 182-196.

HIGUCHI, R., BOWMAN, B., FREIBERGER, M., RYDER, O.A. \& WILSON, A.C. 1984. DNA sequences from the quagga, an extinct member of the horse family. Nature 312: 282-284.

HIGUCHI, R.G., WRISCHNIK, L.A., OAKES, E., GEORGE, M., TONG, B. \& WILSON, A.C. 1987. Mitochondrial DNA of the extinct quagga: relatedness and extent of postmortem change. J. Mol. Evol. 25: 283-287.

KLEIN, R.G. \& CRUZ-URIBE, K. 1999. Craniometry of the genus Equus and the taxonomic affinities of the extinct South African quagga. S. Afr. J. Sci. 95:81-86.

LEONARD, J.A., ROHLAND, N., GLABERMAN, S., FLEISCHER, R.C., CACCONE, A. \& HOFREITER, M. 2005. A rapid loss of stripes: the evolutionary history of the extinct quagga. Biol. Lett. 1: 291-295.

LORENZEN, E.D., ARCTANDER, P. \& SIEGISMUND, H.R. 2008. High variation and very low differentiation in wide ranging plains zebra (Equus quagga): insights from mtDNA and microsatellites Mol. Ecol. 17: 2812-2824.

LOWENSTEIN, J.M. \& RYDER, O.A. 1985. Immunological systematics of the extinct quagga (Equidae). Experientia 41: 1192-1193. 
PARSONS, R., ALDOUS-MYCOCK, C. \& PERRIN, M.R. 2007. A genetic index for stripe pattern reduction in the zebra: the quagga project. S. Afr. J. Wildl. Res. 37: 105-116.

RAU, R.E. 1974. Revised list of the preserved material of the extinct Cape colony quagga, Equus quagga quagga (Gmelin). Ann. S. Afr. Mus. 65: 41-87.

RAU, R.E. 1978. Additions to the revised list of preserved material of the extinct Cape colony quagga and notes on the relationship and distribution of southern plains zebras. Ann. S. Afr. Mus. 77: 27-45.

SKEAD, C.J. 1987. Historical Mammal Incidence in the Cape Province Volume 2: The eastern half of the Cape Province, including the Ciskei, Transkei and East Griqualand. Republic of South Africa: Department of Nature and Environmental Conservation of the Provincial Administration of the Cape of Good Hope, Cape Town.

Corresponding Editor: M.I. Cherry 